\title{
DEĞERLİ BİR ÇILGINLIK VE HATA: FOUCAULT (FOUCAULT VE FAULT - HATA/ARIZA)
}

\section{WORTHY MADNESS AND MISTAKE: FoucAULT (FOUCAULT AND FAULT - ERROR)}

Mustafa Hulki CEVizoĞLU*

ÖZ: Bu makalede; Fransız sosyolog ve filozof Michel Foucault'nun ürettiği temel kavramlar olan özne, öznenin ölümü, benlik, iktidar, temel iktidar türleri (mutlak iktidar, disipline edici iktidar, biyo-iktidar), ceza, söylem, bilginin arkeolojisi, soykütük, dispositif, arşiv ve episteme ele alınmaktadır. Ayrıca, iktidar ile beden ilişkileri, iktidar ile tahakküm ilişkileri incelenmektedir. Bu kavramlar ve değerlendirmeler içinde hem kendisinin post-yapısalcı olmasına karşın bunu kabul etmemesi ve hem de temel görüşleri arasındaki çelişkiler kendi ifadeleriyle ortaya konmaktadır. En temel çalışmalarından olan "iktidar" konusunda bir yandan iktidarın (diğer ifadesiyle; tabi kılma kurumlarının) baskıcı ve tahakkümcü olmadığını söylemekte; öte yandan da, iktidarın toplumun rıza göstermesi ve bir uzlaşma (konsensüs) ile ilgisi olmadığını ileri sürmektedir. Büyük Kapatılma kavramı bile büyük bir tahakküm ve bunun sonucunda "Öznenin ölümü" demektir. Foucault'nun, makro çapta siyasal iktidarı değerlendirirken konuyu "cinsel iktidar" kavramına getirerek mikro düzeye (tikel ve mikro iktidar) indirgeyerek kafa karıștırması da anlaşılır değildir. Bir başka tartışma noktası ise, "çocuk cinselliği", "işkence" ve "uyuşturucu" gibi temel konularda karşımıza çlkmaktadır. İnsan bilimlerinin arkeolojisini yaptığı Kelimeler ve Şeyler'de de yaklaşık 550 sayfa düşünce üretmesine karşın, dilin ne olduğu konusunda hâlâ kararsızdır ve bu temel soruların yanıtını bulamamıştır.

Anahtar Kelimeler: İktidar, özne, söylem, bilginin arkeolojisi, soykütük.

ABSTRACT: In this article; The basic concepts produced by the French sociologist and philosopher Michel Foucault, the subject, the death of the subject, the self, power, basic types of power (absolute power, disciplinary power, bio-power), punishment, discourse, the archeology of knowledge, genealogy, dispositif, archive and episteme is addressed. In addition, the relationship between power and body, and the relations of power and domination are examined. Within these concepts and evaluations, the contradictions between both his own poststructuralist and his refusal to accept this and his basic views are revealed with his own expressions. With regard to "power", which is one of his most fundamental works, he says on the one hand that power (in other words, institutions of subordination) is not oppressive and domineering; On the other hand, he argues that power has nothing to do with the consent of the society and a consensus. Even the concept of the Great Closure means great domination and the consequent "death of the Subject". It is also not understandable that Foucault, while evaluating political power on a macro scale, confused the issue by bringing it to the concept of "sexual power" and reducing it to the micro level (particular and micro power). Another point of discussion arises in fundamental issues such as "child sexuality", "torture" and "drugs". Although he produced about 550 pages of thought in Words and Things, where he made the archeology of human sciences, he is still undecided about what language is and could not find the answers to these basic questions.

Keywords: Power, subject, discourse, archeology of knowledge, genealogy.

* Dr. - Başkent Üniversitesi Fen-Edebiyat Fakültesi Sosyoloji Programı/Ankara hulkicevizoglu@cevizkabugu.com.tr (Orcid ID: 0000-0002-0915-903X) 


\section{Giriş}

"Deliliğin Tarihi", "Kliniğin Doğuşu", "Kelimeler ve Şeyler", "Bilginin Arkeolojisi", "Gözetleme ve Cezalandırma: Hapishanenin Doğuşu", "Bilme İstenci", "Cinselliğin Tarihi" ve "Söylenmiş ve Yazılmışlar" (Foucault, 2011: 710) adlı eserler sosyoloji ve psikolojiye büyük katkılar sağlayan eserlerin ilk sıralarında yer almaktadır. Sosyoloji alanındaki çalışmaları kadar felsefe ve psikoloji (psikopatoloji ve deneysel psikoloji) alanında da çok büyük izler bırakan Michel Foucault (d.15 Ekim 1926, ö.25 Haziran 1984), Louis Althusser'in öğrencisi olarak biyo-iktidar, disipline edici güç, öznenin ölümü, söylem, bilginin arkeolojisi, soykütük, yönetimsellik, dispositif ve arşiv kavramlarını da üreterek bilime büyük katkılarda bulunmuștur. Çok yönlü (boyutlu) bir bilim insanı olan Foucault kendisinin "kategorize edilmesine", kuram oluşturan birisi olarak "tanımlanmasına" karşı çıkar. Örneğin, postyapısalcı olarak "kategorize edilmesi/tanımlanması" konusunda da şunları söyler:

Ben yapısalcı değilim, yapısalcı olduğumu hiçbir zaman söylemedim, hatta yapısalcı olmadığım gerçeği üzerine sık sık durdum ve bunu birçok kez hatırlattım. Hiçbir şey, yayımladığım şeyler içinde kesinlikle hiçbir şey, hiç, ne yöntemlerimde ne herhangi bir kavramımda, uzaktan da olsa yapısalcılığı hatırlatır (Foucault, 2015a: 103).

Bununla kalmaz, kendisini yapısalcı olarak tanımlayanlara da çok kızar. Bu sıfatı, ünlü psikolog Piaget'nin yapıştırdığını söylemeye "tenezzül etmez!" bile, onu yok sayar. Kendisini yapısalcı sanmak için "insanın adının Piaget olması" gerekir, daha da ileri gider "sadece budalalar ve saflar-adları Piaget olabilir-bunu iddia edebilir", bunlar "budalalar, saflar ve cahillerdir" ve o bunları "ciddiye almaz." (Foucault, 2015a: 104) Ancak, bir başka konuşmasında kendisi de benzer tanımlamayı Fransız tarihçi ve dilbilimci Dumézil için yapar ve "Dumézil genellikle yapısalcılığın ataları arasında sayılır, kendinin pek farkında olmayan bir yapısalcı olduğu (...) kesin. Dumézil, kendi tarihsel analiz eserinin bu tür yorumlanmasından memnun değil" der (Foucault, 2015a: 267).

Foucault, yapısalcı olmadığını söylediği halde yapısalcı yöntemlere başvurmuştur. Başvurduğu yöntemlerden birini toplumsal-kolektif bilinçdışını meydana getiren yapıları açıklarken kullanmış ve yönteme başvurma gerekçesini de "analiz etme" zorunluluğu ile açıklamıştır:

Yapısalcıllk bir analiz kipliğinden başka bir șey değildir. Örneğin Delinin içinde bulunduğu koşullar ortaçağdan günümüze nasıl değişti? Bu değişim için gerekli koşullar nelerdi? Yalnızca tüm bunları analiz etmek için yapısalcı yönteme başvuruyorum (Foucault, 2015a: 82).

Foucault'nun temel kavramları ve bu konulardaki görüşlerini, bizzat kendi ifadeleri ve önemli eserlerinden yararlanarak inceleyelim.

\section{Özne (Benlik)}

Foucault "özne" olan birey(benlik) yerine, "benlik teknolojilerine" ve iktidarın kontrol ve tahakkümü altındaki benliği inceleme alanına alır. Ona 
göre, “özne -olan birey- ölmüştür.” Çünkü özne, iktidar tarafından yönetildiği için artık onun tutarlılığından, bilinçli oluşundan ve rasyonelliğinden söz edilemez.

Ona göre 'özne' bir iktidar alanı ve belirli pratikler seti içinde şekillendirilen toplumsal söylemler aracıllğılla üretilen toplumsal bir kurgudur. 'Birey' anlamın yaratıcı kaynağı değildir. Bu nedenle bağımsız olmayan benliğin bilinçli, kendini kontrol edebilen, iç bütünlüğe sahip, tutarlı ve rasyonel varlık olmasından da söz edilemez. Bunu 'öznenin ölümü' ile ifade eder (Baran ve Suğur, 2014: 137).

Foucault'nun çözümlemesinde tarih yapan bir özne olarak insan faktörüne yer yoktur. Foucault sıklıkla Nietzsche'nin iyi bir takipçisi olduğunu ifade etmiști. Nietzsche, tarihsel ve toplumsal özne olarak insanın ölümünü ilan etmişti (Hatipoğlu, 2016: 21).

Foucault hem anlamın kaynağı hem de sosyal analizin kurucu unsuru olarak bireyi merkeze alan bütün hümanizm biçimlerine karşıdır. $\mathrm{Bu}$ anlamda, birey 'merkezden' veya sahnenin merkezinden 'uzaklaştırılır'. Onun yerine, toplumu ve bireylerin 'öznellikler'ini 'inşa eden' nesnel toplumsal formlara yönelmek gerekir (Layder, 2014: 136). O bize merkezsiz bir toplum ve merkezsiz bir birey sunar ve bu anlamda yapısalcı ve hümanist yaklaşımlarla ilgili birçok problemden uzak durur. Bu yüzden, onun iki yaklaşım arasında köprü kurmaya ve düalizmi (birey-toplum düalizmi- HC) aşmaya çalıştığı söylenebilir (Layder, 2014: 149).

\section{Söylem (Discours)}

Söylem Foucault'da genel olarak, "farklı alanlara ait olabilen, fakat her șeye rağmen ortak çalışma kurallarına uyan bir ifadeler birliğini" gösterir (Revel, 2012: 114). Söylem, "belli bir düzeyde, dilbilimsel olguların ve başka bir düzeyde polemik ve stratejik olguların düzenli toplamıdır." Foucault'ya göre, dilsel olguların dilbilimsel karakteri önemlidir ama artık yeni bir değerlendirme anı gelmiştir:

Söylem olgularını sadece dilbilimsel yanları bakımından değil, bir biçimde burada Anglo-Amerikalıların gerçekleştirdiği araştırmalardan esinleniyorum- oyun, games, stratejik etki-tepki, soru-cevap, tahakküm ve siyrılma oyunu olduğu kadar, mücadele olarak da değerlendirme anı gelmiştir (Foucault, 2015a: 165).

"Konuşmak, bir iktidar uygulamaktır; konuşmak, kendi iktidarını riske etmektir; konuşmak, kazanmayı ya da her şeyi kaybetmeyi göze almaktır" (Foucault, 2015a: 264) diyen Foucault'nun analizinde dil, söylem kavramı kadar önemlidir. Çünkü dil olmadan söylem mümkün değildir. İktidar olabilmek için de dilin söylem oluşturması zorunludur.

Ancak, dilin asla 'masum' olmadığını anlamak da önemlidir; o asla tarafsız bir ifade aracı değildir. Söylemler güç ilişkilerinin ifadeleridir ve bu ilişkilerle bağlantılı pratikler ve konumları yansıtırlar (Layder, 2014: 137). Bu yüzden bir söylemin kullanımı, konuşmacının, belirli bir alan hakkındaki bilgisini (örneğin, tıbbî veya hukukî prosedürleri) söylem içinde belirlenen 
ölçütlere göre haklı (veya doğru) olduğunu iddia edebilecek biçimde konumlandırmasını mümkün kılar. (...) Bu türden profesyonel söylemler, kullanıcılara sağladıkları diğerlerini kontrol gücünün en canlı örnekleridir (Layder, 2014: 138).

Foucault "bilginin, bilinçdışına sahip olduğunu" da ileri sürer. Bunu Deliliğin Tarihi'ni yazarken göstermeye çalışmıştır:

Göstermeye çalıștığım şey, söylem biçimlerini, kavramları, kurumları, pratikleri kendi aralarında birbirine bağlayan sistematikliğin ne unutulmuş, örtülmüss, kendinden sapmış radikal bir düşünce ne de Freudcu bir bilinçdışı türünden olduğu; fakat bilginin, kendi özgün biçimleri ve kuralları olan bir bilinçdışına sahip olduğudur (Foucault, 2015a: 34).

Söylemin görevi, olanı söylemek olacaktır, ama söylediğinden daha fazla bir şey olmayacaktır (Foucault, 2015b: 80, 81).

\section{Arkeoloji}

"Arkeolojik analiz" Foucault'nun araştırma yönteminin adıdır. Arkeolojik analizin özellikleri yeniliğin tahsisi, çelişkilerin analizi, karşılaştırmalı betimlemeler ve dönüşümlerin tespiti konusundadır. 0 , şu tanımı yapar:

Bana göre arkeoloji şudur: Geçmiş ile bugün arasındaki benzerlik ilişkilerine değil, daha ziyade, süreklilik ilişkilerine ve mücadele stratejisinin taktik hedeflerini günümüzde tanımlama imkânı üzerinde -özellikle buna göretemellenen tarihsel-siyasi bir teşebbüstür (Foucault, 2015a: 276).

Foucault, arkeolojiyi "eleştirel bir makineye" de benzetir, "Bazı iktidar ilişkilerini tartışma konusu eden bir makine, özgürleştirici bir işlevi olan, en azından olması gereken bir makine." (Foucault, 2015a: 277).

Arkeolojik analizin amacl, sadece belli tarihsel dönemlere ait söylemsel oluşumlar ile onların içinde yer alan tikel söylemlerin ortaya çıkışını mümkün kılan biçimsel epistemik koşulları açığa çıkarmaktır. (...) Arkeoloji, "şimdiki zamanın tarihini yazabilmek için geçmişte kalan tutarsız, çeliş̧ili kuralları ve izleri incelemekle ilgilidir." (Baran ve Suğur, 2014: 125, 137).

Foucault analizini dört ilkede toplar (Foucault, 2014: 164, 165):

1. Arkeoloji, söylemlerin içinde gizlenen ya da apaçı görünen düşünceleri, temsilleri, imajları, temaları, saplantıları değil de bu söylemlerin kendilerini, kurallara uyan pratikler olarak bu söylemleri tanımlamaya çalışır.

2. Arkeoloji, söylemleri kendilerinden önce gelen, kendilerini çevreleyen ya da izleyen şeye, hoş bir eğilimle bağlayan sürekli ve hissedilmez geçişi yeniden bulmaya çalışmaz. Onun problemi, tam tersine, söylemleri özellikleri içinde tanımlamak; kullandıkları kurallar oyununun başka hiçbir şeye indirgenemediğini göstermek; daha belirgin kılmak için dış hatları boyunca izlemektir. 
3. Arkeoloji bireysel eserlerin içine nüfuz eden, bazen bütünüyle onları yöneten ve hiçbir şeylerini eksiltmeksizin onlara egemen olan; bazen de ancak onların bir kısmını yöneten, söylemsel pratiklerin tiplerini ve kurallarını tanımlar.

4. 0, söylemi kendi özdeşliğinin içine eklemek suretiyle söylenmiş olan şeyi tekrar etmeye çalışmaz. Üstelik o, bir yeniden yazılımdan fazla ve başka hiçbir şey değildir; yani dişsallı̆̆ın sürekli biçiminin içinde, daha önce yazılmış düzenli bir dönüşümü. Bu, kaynağın kendi gizine geri dönüşü değil; nesne-söylemin sistematik bir betimlemesidir.

Foucault Bilginin Arkeolojisi kitabında söylemsel düzlemler, ifade ve arşiv ile arkeolojik betimleme konularına yer verir. Ona göre (Foucault, 2014), arkeoloji, icatların araştırılması değildir, "bayram sabahlarının aydınlığını yeniden oluşturmaya çalışmaz" (s. 170); kendine özgü zamansal kopukluğa sahip olan ve dilde gösterilebilen tüm diğer özdeşlik ve farklılık biçimlerini kendisiyle birlikte taşımayan bir ifadesel homojenlik düzeyini betimler ve bu düzeyde de yoğun, biçimsiz ve ilk ve son kez tümüyle verilmiş bir eşzamanlılığı dışarıda tutan bir düzeni, art arda gelişleri, büsbütün ince bir yolu ortaya koyar, "'çağlar' adı verilen, yeterince karışık bu birliklerin içinde arkeoloji, özgüllükleriyle birbirine eklemlenen fakat kavramların zamanı, teorik dönemler, biçimlenme evreleri ve dilbilimsel evrimin aşamaları konusunda birbirine karışmayan 'ifade dönemlerini' ortaya çıkarıverir" (s. 174); arkeolojik analiz ortak bir biçimi ya da bir temayı açığa çıkarmaya değil, aralarındaki mesafenin değerini ve biçimini belirlemeye çalışır (s. 179); arkeoloji, bir ifadeler bütününün oluşum kurallarını belirler, "arkeoloji, bir söylemin içine girilebilirlik derecesini ve biçimini analiz eder" (s. 196); ve Foucault "arkeolojiyi ne bir bilim olarak ne de gelecek bir bilimin ilk temelleri olarak takdim etmez" (s. 238).

\section{Soykütük (Soybilim)}

Foucaut'nun ürettiği kavramlardan soybilim, ilişkiseldir. Ona göre soybilimin "üç alanla" (hakikatle-iktidar alanıyla-ahlâkla) ilişkilidir. Bunlar birer tarihsel ontolojidir. Bu üç farklı ilişki üzerinden kendimizi -doğal olarak üç farklı biçimde- kurarız (oluştururuz): bilgi nesneleri olarak, etki yapan özneler olarak ve ahlâki failler olarak.

İlk olarak hakikatle ilişkimiz içinde kendimizin bir tarihsel ontolojisi; kendimizi hakikatle bu ilişki üzerinden bilgi nesneleri olarak kurarız. İkincisi, bir iktidar alanıyla ilişkimiz içinde kendimizin bir tarihsel ontolojisi; kendimizi iktidarla bu ilişki üzerinden başkaları üzerinde etkide bulunan özneler olarak kurarız. Son olarak, ahlâkla ilişkilerimizin bir tarihsel ontolojisi; kendimizi bu iliş̧i üzerinden ahlâki failler olarak kurarız (Foucault, 2011: 204).

Foucault'ya göre, arkeoloji farklılık ve benzerliklerin belirlendiği düzleme odaklanıyorsa; soykütük, daha çok iktidar ilişkileri ve bu ilişkilerle biçimlenen politik teknikleri, kullanışlı bilgi formlarını üretmek için 'şeylerin organize olduğu' düzleme odaklanır. Yani söykütük, tekniği ampirik verilere 
dayanarak yapılan "düzenlerin" yapılarının analizidir (Aktaran: Baran ve Suğur, 2014: 126). Başka bir anlatımla; arkeoloji, tarihsel söylemlerin ampirik çözümlenişlerini kapsarken soybilim, tarihsel söylemlerin ve çağdaş dünyada ilgi duyulan konularla ilişkilerinin bir dizi ve eleştirel çözümlenişini üstlenir (Ritzer ve Stepnisky, 2014: 623).

Soykütük, temel olarak bilgi ve kültürün aynı altyapısı ile ilgilenir ki Foucault bunu, güç mekanizmaları sayesinde doğru ve yanlışın temellerinin ayırt edilebileceği bir düzlem olarak da betimler (akt. Baran ve Suğur, 2014: 126).

\section{Arşiv, Episteme, Epistemoloji}

Foucault'da arşiv, belli bir tarihsel dönemin ya da kültürün geçmişte bıraktığı bütün maddi ipuçlarının koleksiyonunu ifade eder. Bu ipuçlarını araştıran bir kişi dönemin tarihsel apriorisini ve bilimini araştıran bir kişi de dönemin epistemisini anlayabilir. Bu kavramlarının hiçbirinin kehanette ya da tahminde bulunma değeri yoktur. Bunlar sadece sınırl tarihsel düzenlerin/kuralların betimlemeleridir (Baran ve Suğur, 2014: 126).

Foucault, Bilginin Arkeolojisi'nde, epistemenin tüketilemez bir alanı açtığını ve bu alanın asla kapatılamaz olduğunu söyler: "Onun bir çağın bütün bilgilerinin kendine bağlı bulunduğu postülatlar sistemini yeniden kurmak gibi amacı yoktur; ama sonsuz bir ilişkiler alanını baștan sona katetmek gibi bir amacı vardır." Üstelik episteme, bir gün görünen sonra da birden bire ortadan silinip gidecek olan hareketsiz bir biçim değildir: "Episteme, kurulan ve bozulan kesilemelerin, dengelemelerin, rastlaşmaların belirsiz hareketlilikteki bir bütünüdür." (Foucault, 2014: 222). Peki episteme, teknik yetersizlikler, zihinsel alışkanlıklar ya da gelenek tarafından konulmuş sınırlar hesaba katıldığında, bir çağda bilinebilen şeyler midir? Hayır, der Foucault.

Foucault, ünlü eseri Kelimeler ve Şeyler: Insan Bilimlerinin Bir Arkeolojisi (The Order of Things: An Archaelogy of the Human Sciences)'nde bilimsel söylemi, episteme ve epistemoloik alanı açıklar. Foucault'daki epistemenin ilk anlamı, dizge, temel düzen ya da ana kod olarak açıklanabilir. Bir bütün olarak yașama yön veren anonim düșünceler, genel kanılar, gerekli inanışlar bu kodlarla belirlenir. Foucault, buradan hareketle, Bilginin Arkeolojisi'ni yapar, yani bilimsel söylemi belirleyen ve yapılandıran kurallar bütününün kodlarının çözümüne girişir (akt. Baran ve Suğur, 2014: 126).

\section{Düzenek (Dispositif)}

Düzenek (dispositif) kavramı Foucault'da 70'li yıllarda görünür ve başlangıç olarak iktidarın maddi operatörlerini, yani iktidar tarafından kullanılan uyruklaştırma (teba yapma) tekniklerini, stratejilerini ve formlarını gösterir. Burada söz konusu olan, pratikler kadar söylemler, harekete geçirici taktikler kadar kurumlardır. Foucault'nun "iktidar düzenekleri”, "bilgi düzenekleri”, "disiplinci düzenekleri” ya da bir "cinsellik 
düzeneği" vb. hakkındaki durumlara göre konuşacak hale gelmesi böyledir (Revel, 2012: 64).

\section{İktidar}

\section{Her Şeyin İktidarı}

Foucault'ya göre toplumdaki iktidar "tek" değildir. Her toplumda çok sayıda iktidar vardır. Foucault iktidar çeşitleri içine "cinsel ilişki iktidarını" da dâhil eder. "Öncelikle tek bir iktidar olduğunu düşünmüyorum, bir toplumda son derece çok, çeşitli, farklı düzeylerde iktidar ilişkileri vardır. (...) Çok farklı iktidar ilişsileri bir kurumda fiili hale gelirler: örneğin, cinsel ilişkilerde iktidar ilişkileri vardır" (Foucault, 2015a: 274). İktidar deyince akıllara baskı ile özdeşlik de gelir. Oysa Foucault, iktidar ile baskının özdeş olmadığını da savunur.

Foucault, öznenin ölümünü kanıtlayabilmek için önce iktidarı geleneksel tanımından çıkarır. İktidar, yasal ve kurumsal yapılar değildir. Toplumun bütün gözeneklerine yayılmış, her yerde var olan bir "ilișki ağıdır". Bir tür bulutumsu yapıdır. Kurumsal iktidar, bu iktidar ilişkilerinden türemez ama ondan destek alır (Hatipoğlu, 2016: 22). Tek bir iktidardan söz edilemeyeceğini ileri süren Foucault, iktidar ilişkilerinin daha ziyade psikiyatri, toplum ve aile açılarından betimlenip, incelenebileceğini söyler. Sovyetler Birliği'ne dikkat çekerken ailedeki, cinsellikteki, fabrikalardaki, okullardaki iktidar ilişkilerinin aynı kaldığı bir rejimle karşı karşıya olduğumuzu; iktidar ilişkilerini "mikroskobik düzeylerde" (okulda, ailede) dönüştürüp dönüştüremeyeceğimizi bilmek gerektiğini vurgular (Foucault, 2015a: 275).

"Her şeyin sosyolojisi" olduğu gibi, Foucault'daki iktidar anlayışını da neredeyse "her şeyin iktidarı" olarak adlandırabilirim. 0, örneğin, ekonomik iktidarı "yeni ve ilginç bir iktidar türü" olarak tanımlar, bu, tabi kılma kurumlarının üçüncü işlevidir. Foucault siyasi iktidardan, hukuksal iktidardan, mikro-iktidardan (hapishanelerdeki gardiyan ve müdürlerin iktidarı) ve epistemolojik iktidardan (bireylerden bilgi elde etme iktidarı) söz eder (Foucault, 2015a).

\section{Temel İktidar Türleri}

Foucault'daki iktidar türlerinin çokluğuna rağmen temel iktidar türleri mutlak iktidar, disipline edici iktidar ve asıl biyo-iktidardır.

Iktidar, toplumdaki en küçük seviyelerdeki ilişkilerde de aranmalıdır. Feodal ve monarşik sistemlerde tebaları üzerinde sınırsız olarak kullanılan iktidar "mutlak iktidar"dır. 18 ve 19. yüzyılda gelişmeye başlayan ve bireylerin davranışlarını düzenleyen ve kontrolü için gözetim teknikleri geliştiren iktidarı, "disipline edici iktidar", modern çağda ortaya çıkan ve söylemler aracılı̆̆ıyla doğrudan insan bedenini kontrol altına alan iktidarı ise "biyo- 
iktidar" olarak tanımlar. Bilgi, söylemler aracılı̆ıyla üretilir ve iktidarın kendisidir (akt. Baran ve Suğur, 2014: 137-138). ${ }^{1}$

\section{Mutlak İktidar}

Ona göre, feodal düzende ve monarşik sistemlerde güç/iktidar, tebaları üzerinde sınırsız bir güce sahip hükümran bir kişide cisimleşir. Bu sistem tipinde suç, monarkın mutlak gücüne/iktidarına karşı bir tehdit olarak algılanır ve suçlunun herkesin gözü önünde ve ibret verici biçimde cezalandırılması gerektiği düşünülür. Bu uygulama, olaya şahit olanların yüreğinde çarpıcl bir terör yaratarak monarkın ve yönetici sinıfin gücünü/iktidarını yeniden teyit eder (Layder, 2014: 139).2

Foucault, Hapishanenin Doğuşu'nda (2013) mutlak iktidar dönemine ilişkin çok ayrıntılı işkence ve "azap çektirmenin görkemi" sahnelerine yer verir. Bu tür iktidar dönemlerinde cezalar "insani değildir", acı çektirme bir sanat olarak uygulanmaktadır, insan bedeni kopartılmakta, parçalanmakta, yüzüne veya omuzuna simgesel olarak monarkın damgaları basılmakta, canlı ya da ölü olarak teşhir edilmekte, suçlu seyirlik unsur haline getirilmekte ceza ise karanlık bir şenlik haline çevrilmektedir (2013: 39). Acı sahnelenmektedir (2013: 47). Gösterişli cezalandırma törenleri beden ve kan ögeleri üzerine kurulmaktadır. Adaletin cezalandırıcı aygıtı bedenin bizatihi kendisidir (2013: 51). Suç asıl kurbanın dışında, hükümdara da (monarkın kendisine) kişisel saldırı olarak kabul edilmektedir, çünkü yasa hükümdarın iradesidir ve yasanın gücü hükümdarın gücüdür (2013: 91). Azap çektirme törenlerindeki baş kişi halktır, çünkü suçlunun üzerinde şiddet uygulayan "iktidarın seyri" ile dehşet/terör etkisi yaratılmakta ve korku üretilerek monarkın iktidarı güvence altına alınmaktadır (2013: 105, 106).

Foucault'nun yalnızca feodal-monarşik düzenlere özgü olarak sınıflandırdığı ve geçmişte kaldığını iddia ettiği "mutlak iktidar" biçimi, günümüzde de mevcuttur. Sisteminin adı "demokrasi" de olsa bazı ülkelerde(!), tek adamlık arzusunun ya da derin emperyal devlet aygitının zehirlediği uygulamalar vardır ve feodal düzenlerdeki "herkesin gözü önünde" kavramı "TV ekranları önünde” ye dönüşmüştür ve her iki sistemde de cezalandırmalar "canlı"dır. Darağacı ya da işkence meydanları, TV stüdyoları ve ekranları olmuştur. Ya da; savaş adı altındaki silahlı saldırılarda, canlı bomba veya bombalı araçla yapılan katliamlardaki yüzlerce parçalanmış bedenin ekranlarda "canlı" olarak gösterilme "mekânları", eski feodalitenin işkence meydanları/mekânlarının yerini almıştır.

\section{Disipline Edici İktidar}

...toplumsal ortopedi diye adlandırdığım çağa giriyoruz. Geçmişte gördüğümüz tamamen cezalandırmaya dayalı toplumlara karşıt olarak

\footnotetext{
1 İtalik vurgulamalar yazara aittir.

${ }^{2}$ Çoklu vurgulamalar yazara aittir.
} 
disipline edici toplum diye belirttiğim bir toplum türü, bir iktidar biçimi söz konusudur. Bu, toplumsal denetim çağıdır (Foucault, 2015a: 223, 224).

Foucault, bu iktidar biçiminin, bu genelleşmiş ortopedi toplumunun ünlü ve küçük bir modelini İngiliz filozof Bentham'ın Panoptikon ve Panoptizm ile ortaya koyduğunu söyler. Ona göre bu, disipline edici toplumun kökenidir. Panoptikon, halka biçimli bir binadır, ortasında bir avlu ve avlunun ortasında da bir kule vardır. Halka, hem içeriye hem dışarıya bakan hücrelere bölünmüştür. Merkez kulede bir gözetmen vardır. $\mathrm{Bu}$ gözetmen, kendisinin her şeyi görebileceği, buna karşılık kimsenin kendisini göremeyeceği şekilde, panjurlar, yarı açık bölme pencereleri arasından gözlemde bulunur. Panoptikon aslında, bir toplum ve bir iktidar türünün kopyasıdır., bunlar aslında fiilen gerçekleşmiş olan ütopyadır. Bu tür bir iktidar, panoptizm adını tam olarak alabilir. Panoptizmin egemen olduğu bir toplumda yaşıyoruz (Foucault, 2015a).

Panoptizm, toplumumuzun karakteristik özelliklerinden biridir. Kişisel ve sürekli gözetim biçimi altında, denetim, cezalandırma ve ödüllendirme biçimi altında ve ıslah biçimi altında, yani bireylerin bazı kurallara göre dönüştürülmesi ve şekillendirilmesi biçimi altında bireylere uygulanan bir iktidar biçimidir bu. Panoptizmin bu üçlü yanı -gözetleme, denetim ve ıslahtoplumumuzda var olan iktidar ilişkilerinin temel ve karakteristik bir boyutu gibi durmaktadır (Foucault, 2015a: 236-237).

Büyük Kapatılma'yı Türkçe yayıma hazırlayan ve aynı zamanda çevirmenlerinden (diğeri Işık Ergüden) olan Ferda Keskin, panoptikonu şöyle özetler: "Panoptikon'da gözleyenin kendisi gözlenenler tarafından görülmediği için gözlenenler tam olarak ne zaman gözlendiklerini bilemezler. Bu yüzden her zaman sanki gözleniyormuş gibi hareket etmek ve davranışlarını sınırlandırmak zorundadırlar. İşte tam da bu yüzden Foucault'ya göre Panoptikon, disiplinin mahkûmlar tarafından içselleştirilmesidir. Panoptikon ilkesinin hapishane dışında başka kurumlar tarafından da uygulanmasıyla birlikte iktidar son derece ekonomik, verimli ve etkili bir şekilde toplumu disiplin altına alır (Foucault, 2015a: 18).

Foucault, Hapishanenin Doğuşu'nda panoptikon sistemi için “Ne kadar kafes varsa, o kadar küçük tiyatro vardır, bu tiyatrolarda her oyuncu tek başınadır, tamamen bireyselleşmiştir ve sürekli olarak görülebilir durumdadır" der ve devam eder:

Görülmeden gözetim altında tutmaya olanak veren düzenleme, sürekli görmeye ve hemen tanımaya olanak veren mekânsal birimler oluşturmaktadır. Sonuç olarak, hücre ilkesi tersine döndürülmekte veya daha doğrusu onun üç işlevi -kapatmak, ışıktan yoksun bırakmak ve saklamaktersyüz edilmektedir; bunlardan yalnızca birincisi korunmakta, diğer ikisi kaldırılmaktadır. Tam ışık altında olma ve bir gözetmenin bakışı, aslında koruyucu olan karanlıktan daha fazla yakalayıcıdır. Görünürlük bir tuzaktır (Foucault, 2013: 296). ${ }^{3}$

3 İtalik vurgulamalar yazara aittir. 
Disipline edici iktidar biçimi, ona göre, 17 ve 18. yüzyıllarda ortaya çıkmıştır. Bu iktidar biçimi, insanlara sürekli fizik cezalar uygulamaktan ziyade, onları sürekli gözetim altında tutmaya çalışır. Bu başlangıçta cezaevleri, kışlalar, tımarhaneler ve manastırlarda uygulanırken sonraları hastaneler, okullar ve fabrikalarda da uygulanmaya başlamıştır (Layder, 2014). Foucault'ya göre (Foucault, 2013: 51, 174), bu “önemli an"dır. Gösterişli cezalandırma törenlerinin eski ikizi beden ve kan, yerlerini maskeli bir kişiye bırakmaktadır. Trajedinin yerini siluetler, yüzü olmayan sesler, dokunulması olanaksız varlıklar almakta ve trajedi komediye dönüşmektedir. "Adaletin cezalandırıcı aygıtı artık bu bedeni olmayan gerçeğe taşmak zorundadır." Eski mutlak iktidar döneminde (feodalitede), hükümdar, mahkûmların bedenine kendi (iktidarının/gücünün) fiziki damgasını basıyordu. Mahkûmlar, kralın nesnesi haline gelmekteydi. Bu yeni disipline edici iktidar döneminde ise, daha çok kamunun malı ve nesnesi olmaktadır.

Foucault bu iktidar biçimini "mekânsal" düşünmüş, teknolojik gelişmeleri öngörememiştir. Günümüzdeki bilgisayar teknolojileri, akıllı telefon uygulamaları, televizyon ve kameralar, akışkan gözetimler, kimlik bilgileri ve kredi kartları ve benzeri pek çok yöntem "küreselleşmiştir".

\section{Biyo-İktidar}

Foucault, 17. yüzyılın sonundan itibaren "yeni bir iktidar" biçimi oluştuğunu ileri sürer. "Biyo-iktidar" olarak tanımladığı bu yeni iktidar biçimi, yaşama iki şekilde müdahale etmektedir:

1- Disiplinci iktidar (insan bedenini bir makine olarak görür),

2- Nüfusun biyo-politiği (bedeni bir doğal tür olarak görür.) Biyoiktidar "tahakkümcüdür" (zorba, hükmedici), "hegemonya" (baskı, üstünlük) kurar (Foucault, 2011: 16-17).

İktidarın bedenlerimize hâkim olduğunu belirten Foucault, bunun sağlam, sağlıklı ve estetik vücut imajı ile ilişkisine işaret eder. Beden eğitimi, jimnastik, idmanlar, kas geliştirme, çıplaklık, güzel bedenin yüceltilmesi gibi vurgular, iktidadrın çocuklar, askerler ve diğer insanların bedenleri üzerinde kararlılıkla uyguladığı bir çalışmaya işaret ederler (Hatipoğlu, 2016: 23, 24).

Foucault'ya göre, tabi kılma kurumlarının ikinci işlevi, bireylerin bedenlerini denetlemektir. Bireyin bedeni belirli bir sistem içinde denetlenir, oluşturulur ve değerlendirilir. "Beden, 18. yüzyıldan itibaren eziyet ve cezaların kaydolduğ u yüzeydir."

19. yüzyıldan itibaren ortaya çlkan kontrol mercilerinde beden tamamen farklı bir anlam edinir; artık eziyet edilmesi gereken bir şey değil, oluşturulması, ıslah edilmesi, düzeltilmesi gereken şeydir, yetenek kazanması, bazı nitelikler edinmesi, çalışabilir beden olma niteliğini kazanması gereken şeydir (Foucault, 2015a: 248-249).

Tabi kılma kurumları (iktidarlar) bedenleri, belirli bir norm çerçevesinde "normalleştirme aygıtına" bağlar. Artık "dışlama yoluyla 
içerme" söz konusudur. Ona göre, okullar, fabrikalar vb. tüm bu total kurumların amacı bireyleri dışlamak değil "sabitlemektir" (Foucault, 2015a: 245).

Modern biyo-iktidar cinselliği de bastırmaz, onu üretir ve bedene nüfuz etmek için bireylere dayatır.

Biyo-iktidar gibi modern güç biçimleri 'kapatmak', engellemek ve genellikle reddetmekten ziyade, kontrol ve itaat yolları geliştirir. Psikiyatri, tıp, sosyal hizmetler gibi oldukça farklı profesyonel söylemlerin yanı sıra, sosyoloji ve kriminoloji gibi disiplinlerin ortayı çıkışı da yeni güç tekniklerinin gelişimi, rafine edilmesi ve çoğalmasına katkıda bulunmuştur (Best ve Keller'den akt. Layder, 2014: 142).

\section{İktidar Beden İlişkisi}

Foucault, 70'li yıllardaki analizleri ile bedeni her şeyden önce "işkencelerin ve cezaların bir kaydedilme yüzeyi" olarak incelemenin söz konusu olduğu bir iktidar kavramından, tam tersine, "bedene biçim vermeye, düzeltmeye ve yeniden biçim vermeye çalışan" başka bir iktidar kavramına nasıl geçildiğini anlamaya çalışır (Revel, 2012: 23).

Foucault'ya göre beden, ancak hem "üretici bir beden", hem de "tabi kılınmış bir beden" olduğunda "kullanışlı bir güce" dönüşür. Bir bedene dayatılan iktidar, bedenin siyasal teknolojisinin bir parçası olarak anlaşılmalıdır Butler'a göre (Butler, 2012: 276). Foucault "beden"i hem insan hem de kurum olarak kullanır.

"Otoriter iktidar biçimlerine karşı çıkarken, kim olduğumuzdan habersiz hale geliriz. Neden böyle olur?" Butler, şöyle cevap verir:

İktidarın kim olduğumuzun imal edilmesi ve kendimize atıfta bulunma ve nihayetinde kendimizi temsil etme biçimlerinin kısıtlanması süreçlerine doğrudan dâhil olduğu bilinmektedir. Foucault bu türden hareketleri, karşı çıtıkları şey üzerinden nitelerken bunu açıkça ifade eder" (Butler, 2012: 282).

\section{İktidar ve Tahakküm İlişkisi}

Foucault, iktidar/güç/otorite'nin rızaya dayalı olduğunu düşünmez. 0 , iktidarın bir "konsensüs", özneler arası bir alan, ortak bir eylem olabileceği düşüncesini çürütür (Foucault, 2011: 274).

Foucault'nun bilgi sosyolojisinde "Global olarak yoğunlaşmış ya da dağılmış biçimde bir iktidar" yoktur: "Yalnızca 'birilerinin' 'başkalarına' uyguladığı iktidar vardır." Ona göre, iktidar yalnızca "edimde" vardır. "Bunun başka bir anlamı da, iktidarın rıza göstermeyle bir ilgisi olmadığıdır. İktidar kendi başına özgürlükten vazgeçilmesi, hakların devredilmesi, tek tek herkesin sahip olduğu iktidarı birkaç kişiye emanet etmesi değildir; iktidar ilişkileri önceden var olan ya da durmadan yinelenen bir rızanın ürünü olabilir; ama, kendi doğası gereği, bir konsensüsün dışavurumu değildir" (Foucault, 2011: 73). 
İktidarın(otoritenin) rızaya dayalı olmadığını vurgulayan Foucault, "boyun eğdiren" (tahakkümcü, hegemonik) otoriteyi savunur da ("iktidar kötüdür" diyen Sartre'a cevap verirken): "Nedense bu fikir ("iktidar kötüdür"-HC) genellikle bana atfedilmiştir. Oysa benim düşüncelerimle yakından uzaktan ilgisi yoktur" (Foucault, 2011: 244).

İktidar kötü değildir. İktidar stratejik oyunlardır. İktidarın kötü bir şey olmadığını aslında çok iyi bilmekteyiz. Örnek olarak cinsel iliş̧iye ya da aşk ilişkilerine bakalım. Şeylerin kolayca tersine çevrilebileceği açık bir stratejik oyunda bir başkası üzerinde iktidar uygulamak kötülük değildir. Bu, sevginin, tutkunun, cinsel zevkin bir parçasıdır (Foucault, 2011: 244).

Foucault, bu konuda pedagojik alanda haklı eleştiriler yapıldığını hatırlatarak, o eleştirilere "Ben bu sorunların hukuk kuralları, bununla ilişkili rasyonel yönetim teknikleri, ethos, kendilik pratikleri ve özgürlük çerçevesinde ortaya konulması gerektiği kanısındayım" sözleriyle karşılık verir (Foucault, 2011: 244).

$\mathrm{Bu}$ ethos", Foucault'nun "Aydınlanmanın şantajı" olarak nitelediği şeyin reddedilmesini içerir. (Ona göre Aydınlanma, hâlâ büyük ölçüde bağlı olduğumuz bir siyasi, ekonomik, toplumsal, kurumsal ve kültürel olaylar bütünü olarak, ayrıcalıklı bir analiz alanı oluşturur. Foucault'ya göre, "Ya Aydınlanma'yı kabul eder ve onun rasyonalizminin çerçevelediği gelenek içinde kalırız ya da Aydınlanma'yı eleştirir ve onun rasyonalite ilkelerinden kurtulmaya çalıșız.") Kendimizi tarihsel olarak belli bir ölçüde "Aydınlanma tarafindan belirlenmiş varlıklar" olarak analiz etmeye çalışmamız gerekir (Foucault, 2011: 185).

Foucault'ya göre, rızaya dayanmasa da iktidar kötü değildir! Bunu anlayabilmek için onun, bir anlamda, "Bilen, iktidar (otorite, güç) sahibidir" biçiminde özetlenebilen şu sözlerini bilmek gerekir:

İktidar ilişkileri her yerden geçer: İş̧̧i sınıfı iktidar ilişkilerine aracılık eder, iktidar ilişkileri uygular. Öğrenci olarak siz de şimdiden belli bir iktidar konumuna dâhilsiniz; ben, profesör olarak, ben de bir iktidar konumundayım; bir iktidar konumundayım çünkü bir kadın değil, erkeğim ve siz bir kadın olduğunuzdan siz de bir iktidar konumundasınız, aynı değil, ama biz hepimiz iktidar konumundayız. Bir ssey bilen herkese 'iktidar uyguluyorsunuz' diyebilirsiniz (Foucault, 2011: 161).

\section{Sonuç: FoucAULT (Foucault ve Fault - Hata, Arıza)}

Konuşurken sözünün kesilmesinden hoşlanan ve "Konferans verirken sözümün kesilmesinden hoşlanırım: içinizden bazıları ... sözümü kessinler. Konferansı... tartışma ya da itiraz biçimine dönüştürmek istiyorum" diyen Foucault'nun bilime kazandırdığı temel kavramlarının anlam ve kullanıldığg yerleri, kendi temel eserlerinden inceledikten sonra eleştirel bir değerlendirme ile sonuçlandıralım.

${ }^{4}$ Ethos: Kültür, toplumun niteliği, ruhu, tini. 
Eserlerinde özne ve bilinç felsefesi egemen olan Foucault'nun sosyolojik analizleri, sosyoloji olarak anlaşılmak istendiğinde, anlaşılması çok zor metinler olarak karşımıza çıkmaktadır. Bunda, pek çok sosyoloğun gereken birçok yerde örnekleme yapmama alışkanlığının da etken olduğu söylenebilir. Foucault'nun görüşleri felsefi metinler olarak düşünüldüğünde anlaşılması daha kolay olmaktadır. Onun eserlerini/çalışmalarını "siyaset ve toplum felsefesi" ya da "sosyal tarih" çalışması olarak değerlendirmek mümkündür. "Ben bir tarihçiyim" sözünün gerçekliğini birçok çalışmasında görmekte ve bir "tarih felsefesi" ile karşılaşmaktayız.

Onun en temel kavramsal çalışmalarından olan "iktidar" konusunda fikirleri net değildir. Foucault, bir yandan "Ikktidar baskı yapmaz; en azından bazı kişilere zevk sağlar. Tüm bir libidinal zevk düzeni, tüm bir iktidar erotiği vardır; bu, iktidarın sadece baskıcı olmadığına kanıtlar" sözleriyle iktidarın (tabi kılma kurumlarının) baskıcı-tahakkümcü olmadığını söylerken; öte yandan, "iktidarın rıza göstermeyle bir ilgisi olmadığıdır. (...) Bir konsensüsün dışavurumu da değildir" sözleriyle de iktidarın rıza göstermeyle/konsensüsle bir ilgisi olmadığını ileri sürmektedir. Büyük Kapatılma kavramı bile, kendi başına büyük bir tahakkümün varlığını kanıtlamaktadır. "Kapatılma", başka bir güç tarafından edilginleștirilme, etkisizleştirilme, nesneleştirilme demektir. “Öznenin ölümü”(!) demektir. Özneyi öldüren iktidara net biçimde tahakkümcü dememek anlaşılır gibi değildir.

Hataları (faulties) Büyük Kapatılma'dan yola çıkarak vurgulamak istediğimizde karşımıza çelişki çıkmaktadır. Foucault'ya göre, bir yandan tabi kılma kurumlarının ikinci işlevi "bireylerin bedenlerini denetlemek, Islah etmek ve düzeltmektir." Bunu belirli bir norm çerçevesinde "normalleştirme aygıtına" bağlamak ve "dışlama yoluyla içermek", bir iktidar tahakkümüdür. Özne ve Íktidar'da söylediği gibi ona göre tahakküm aslında global bir iktidar yapısıdır, iktidarın işleyişi bazılarının başkaları üzerinde eylem kipidir; iktidar ilişkileri, kendi doğası gereği, bir konsensüsün dışavurumu değildir; iktidarın esas niteliği şiddettir, şiddet iktidarın değişmeyen sırrı ve başvurduğu son şeydir. Ve yine ona göre "biyo-iktidar" veya "anatomo-siyaset" diye adlandırılan şeyin ortaya çıkışından bu yana, artık bir hukuk toplumu olmaya son vermekte olan bir toplumda yaşamaktayız. Bütün bunlar iktidarların tahakkümcü olduğunu göstermektedir.

Foucault, benzer biçimde İktidarın Gözü'nde araştırmalarının iktidar tekniklerine, iktidar teknolojisine yönelik olduğunu, iktidarın nasil tahakküm uyguladığını ve kendine itaat ettirdiğini incelemekten ibaret olduğunu ifade etmektedir. Bu ifadeler de iktidarların yapısının tahakkümcü olduğunu ileri sürmektir.

Foucault'nun, makro çapta siyasal iktidarı değerlendirirken konuyu "cinsel iktidar" kavramına getirerek mikro düzeye (tikel ve mikro iktidar) indirgeyerek kafa karıştırması da anlaşılır değildir. Zaten iktidarı "Göz kamaştırıcı hayvan" olarak tanımlaması da iktidarın evcil olmadığını gösteren ve tartışmayı sonlandıran net bir kanıttır. 
Foucault'nun iktidar oluş konusundaki tanımlaması da tek yönlüdür. Onun, iktidarların kendi söylemini kurmadığı ve tam aksine kendi çıkarlarını söylem haline getirenlerin iktidara yürüdükleri tezi doğru olmakla birlikte, iktidara gelenlerin sürekli söylem değiștirerek yeni gerçeklikler oluşturdukları gerçeğini dışarda bırakmaktadır. Çünkü birçok iktidar modelinde, bir biçimde iktidara gelenlerin -kimi zaman birbiriyle büyük zıtlık içeren- farklı söylemler geliştirerek iktidarlarını tekrar ve tekrar ürettiklerine tarih boyunca tanık olunmuştur. Sonuç olarak iktidar da kendi söylemini kurar ve sürdürür, kendi çıkarlarını söylem haline getirebilen gruplar da iktidar olabilir. Bu durumdakiler iktidar olduğunda birinci durum geçerli olur (iktidar söylemini kurar ve sürdürür). Düalizmleri aşma çabasındaki Foucault, bu noktada kendisi "yeni bir düalizm" yaratmaktadır: söylem-iktidar düalizmi (karşıtllğı).

Ucu açık -sonlandıracak kanıtını henüz görmediğim- başka bir tartışma ise, "çocuk cinselliği", "işkence" ve "uyuşturucu" gibi diğer temel konularda karşımıza çıkmaktadır. Foucault, yetişkinlerin çocuklarla cinsel ilişkisini onaylamakta, işkence ve uyuşturucu kullanımında iyi-kötü ve soylu yüceltmesi yapmaktadır.

Çocuk cinselliğini (çocuğa cinsel yaklaşımı) onaylarken, özgür irade yetisine henüz kavuşmamış çocukların nasıl olabileceğini anlayamadığımız "rızasını"(!) yeterli görmekte ve böylece çocuk suiistimalinde cezaya karşı çıkmaktadır. "On yaşındayken bir yetişkinin üstüne atlayan çocuklar var -o halde? Rıza gösteren, hoşnut kalan çocuklar var. (...) Şunu diyebilirim: Çocuk reddetmediği sürece, yapılanı cezalandırmanın hiçbir gerekçesi olamaz" sözleri bunun kanıtıdır.

Foucault, kendi ifadesiyle "sözcükleri zorlayarak" işkenceyi de "soylu" ve "pis" olmak üzere ikiye ayırmakta ve cellat kurallara uyduğu sürece engizisyon işkencesini de soylu bulmaktadır. Ona göre, işkence, 18.yüzyıla kadar ortaçağın hukuk pratiğinde, gerçek bir ritüeldi ama oldukça kodlandırılmıştı. İşkence celladın ellerinde 'serbest' değildi. 19. ve 20. yüzyılın icat ettiği şey, 'vahşi' işkence idi. Engizisyonun kullandığı işkenceden son derece farklılık taşıyordu.

İnsan bilimlerinin arkeolojisini yaptığı Kelimeler ve Şeylerde yaklaşık 550 sayfa düşünce üretmesine karşın, dilin ne olduğu konusunda hâlâ kararsız olduğunu "Dil nedir? Bir işaret midir? Bütün bunlar konuşurlar mı ve hangi dili, hangi gramere göre konuşurlar? Dil ile varlık arasında hangi ilişki vardır? Şu hiçbir șey söyleyemeyen, hiç susmayan ve kendine "edebiyat" diyen dil nedir?" sözleriyle ifade etmektedir. Ve, "Gerçeği söylemek gerekirse, ne bu sorulara cevap vermeyi ne de bu alternatiflerden hangisini seçmenin gerektiğini biliyorum" cümleleriyle de bu temel soruların yanıtını bulamadığını açıkça kabul etmektedir.

"FoucAULT" (Delilik ve Hata) tanımlaması yapmamın son örneği de, onun uyușturucu kullanımını "zevkli hale getirmeyi" savunmasıdır. Şu sözler bu savunmasının belgeleridir: "Uyuşturucuların kültürümüzün bir parçası 
olması gerektiği kanısındayım. (...) Zevk kaynağı olarak. Uyuşturucuları denemeliyiz. Çok yoğun bir zevk üretmeye elverişli 'iyi' uyușturucular imal etmeliyiz. (...) İyi müzik ve kötü müzik olması gibi, iyi ve kötü uyuşturucular da vardır."

Kendisi de psikoloji eğitimi alan ve iki yıl boyunca akıl hastanesinde görev yapan Foucault'yu daha iyi anlayabilmek için, "odipus yoktur" diyerek ağır eleştirdiği Freud'un "psikanalitik" kuramı açısından da incelemenin uygun olacağı düşünülmektedir.

Foucault'nun bazı düşünce ve kavramlarında gördüğümüz çelişkileri, kendi adı üzerinden bir scrabble (dilmece) yaparak analiz etmek hem farklı hem de zevkli bir analiz kipliği ve yöntem denemesidir. Adının ilk hecesi (fou) Fransızca deli, çılgın anlamına gelmektedir. Foucault sözcüğü aynı zamanda hatayı da (fault) barındırıyor. Delilik ve hatanın birleşimi (FoucAULT), zaten ancak onun gibi bir büyük düşünürde olabilirdi.

\section{KAYNAKÇA}

Baran, A. G. - Suğur, S. (Ed.) (2014). Çağdaş sosyoloji kuramları. 3. b., Eskişehir: Anadolu Üniversitesi.

Butler, J. (2012). Bedenler ve iktidar, tekrar. (Çev.: Șeyda Öztürk), Cogito, S. 70-71, İstanbul: Yapı Kredi.

Foucault, M. (2011). Özne ve iktidar. (Çev.: Işık Ergüden - Osman Akınhay), 3. b., İstanbul: Ayrıntı.

Foucault, M. (2012). İktidarın gözü. (Çev.: Iş̧ı Ergüden), 3. b., İstanbul: Ayrıntı.

Foucault, M. (2013). Hapishanenin doğuşu: Gözetim altında tutmak ve cezalandırmak. (Çev.: Mehmet Ali Kılıçbay), 4. b., Ankara: İmge.

Foucault, M. (2014). Bilginin arkeolojisi. (Çev.: Veli Urhan), 2. b, İstanbul: Ayrıntı.

Foucault, M. (2015a). Büyük kapatılma. (Çev.: Işılk Ergüden ve Ferda Keskin), 4. b., İstanbul: Ayrıntı.

Foucault, M. (2015b). Kelimeler ve şeyler: İnsan bilimlerinin bir arkeolojisi. (Çev.: Mehmet Ali Kılıçbay), 5. b., Ankara: İmge.

Giddens, A. - Sutton, P. W. (2014). Sosyolojide temel kavramlar. (Çev.: Ali Esgin), Ankara: Phoenix.

Hatipoğlu, A. (2016). Tarihsel ve toplumsal koşulları açısından postyapısalcılık: Foucault ve Derrida. Bilim ve Ütopya, S. 268, Yll 22.

Layder, D. (2014). Sosyal teoriye giriş. 4. b., İstanbul: Küre.

Revel, J. (2012). Foucault sözlüğ̈̈. (Çev.: Veli Urhan), İstanbul: Say.

Ritzer, G. - Stepnisky, J. (2014). Sosyoloji kuramları. (Çev.: Himmet Hülür), Ankara: De Ki.

"İyi Yayın Üzerine Kılavuzlar ve Yayın Etiği Komitesi'nin (COPE) Davranış Kuralları" çerçevesinde aşağıdaki beyanlara yer verilmistir. / The following statements are included within the framework of "Guidelines on Good Publication and the Code of Conduct of the Publication Ethics Committee (COPE)":

İzinler ve Etik Kurul Belgesi/Permissions and Ethics Committee Certificate: Makale konusu ve kapsamı etik kurul onay belgesi gerektirmemektedir. / The subject and scope of the article do not require an ethics committee approval.

Çıkar Çatışması Beyanı/ Declaration of Conflicting Interests: Bu makalenin araştırması, yazarlı̆̆ı veya yayınlanmasıyla ilgili olarak yazarın potansiyel bir çıkar çatışması yoktur. / There is no potential conflict of interest for the author regarding the research, authorship or publication of this article. 